\section{Música rap: narrativa dos jovens da periferia de Teresina - PI}

\section{Antonio Leandro da Silva*}

O objetivo deste artigo consiste em discutir a música rap ${ }^{1}$ como uma forma de narrativa contemporânea e a importância do hip hop para a socialização dos jovens ${ }^{2}$ da periferia da cidade de Teresina. ${ }^{3} \mathrm{Mi}-$ nha opção por este tema está diretamente vinculada às minhas experiências, como religioso franciscano, vividas na periferia desta cidade, onde conheci o movimento ${ }^{4}$ hip hop. ${ }^{5}$ Durante seis anos, pude ver, sentir e ouvir as realidades cotidianas vividas por estes sujeitos, e observar como o Rap se tornava o elemento de maior poder e valorização dentro do movimento, recuperando a palavra através das narrativas dos rappers. ${ }^{6}$

Esse texto, portanto, é decorrente de pesquisa realizada com jovens do movimento hip hop durante o curso de mestrado entre o início de 2004 e o término em agosto de 2006 pela PUC/SP. Neste breve artigo, procuramos apresentar a metodologia da pesquisa $\mathrm{e}$ seus respectivos resultados após as análises dos dados, que nos deram maior compreensão do fenômeno sociocultural juvenil e suas implicações para a formação social e racial dos jovens que vivem na periferia de Teresina.

\footnotetext{
* Doutorando pelo Programa de Ciências Sociais da Pontifícia Universidade Católica de São Paulo (PUC-SP), 2006.

10 termo RAP do inglês significa "rhythm and poetry" (ritmo e poesia).

2 Por questões metodológicas, ao mencionar as categorias "jovem" e/ou "juventude", refiro-me ao "jovem" e/ou à "juventude" do movimento hip hop em Teresina, capital do Piauí. Às vezes, refiro-me especificamente ao "jovem negro" e/ou à "juventude negra". Depois, quando falo em juventude tenho em mente uma faixa etária entre os 16 e 24 anos. Conforme definição adotada pela Organização das Nações Unidas ONU - o segmento juvenil representa uma parcela demográfica situada na faixa etária dos 15 aos 24 anos. Porém, este estudo de pesquisa considera jovens os indivíduos com idade entre 16 e 24 anos, porque o limite de 16 anos é considerado idade mínima legal, estabelecida no Brasil para a participação no mercado de trabalho.
} 
ções habituais e conflitantes em que os membros do grupo se encontravam envolvidos; ou mesmo àqueles dados que o grupo considerava de domínio privado. Por isso, procurei transpor possíveis barreiras sociais entre os informantes e o pesquisador, a fim de que a investigação não sofresse implicações na qualidade das informações registradas.

Nesse sentido, os procedimentos técnico-metodológicos nos proporcionaram, de forma ativa, observar e registrar dados da realidade dos sujeitos investigados que contribuíram na textualização final da dissertação. Assim, os instrumentos imprescindíveis para a pesquisa foram: o diário de campo em que descrevemos as experiências dos jovens em questão - os rituais, os gestos, os símbolos, as falas, as práticas culturais - e a entrevista com os sujeitos envolvidos. Como técnica de natureza qualitativa (OLIVEN, 2002), as entrevistas abertas nos ajudaram a obter dados em profundidade acerca do fenômeno estudado. Por meio delas, registramos e descrevemos os momentos e os espaços importantes no processo de sociabilidade urbana dos sujeitos pesquisados. Foram narrativas que revelaram uma realidade juvenil carregada de experiências e vivências cotidianas repletas de significados. As entrevistas livres, além de possibilitar a obtenção de dados referentes aos mais diversos aspectos da vida social dos narradores, facilitaram também a interpretação desses dados (GASKELL, 2002).

O estudo foi realizado com 16 jovens do movimento hip hop de Teresina. Para os encontros com os sujeitos foram agendadas as datas, horas e os locais para as entrevistas, muito embora tivéssemos que, várias vezes, remarcar tais encontros devido aos choques de horário dos entrevistados e suas atividades no movimento. Uma experiência frustrante foi com um ex-integrante do hip hop, por sinal uma pessoa bastante importante no processo de organização do movimento que, ao ser procurado, recusou-se a dar qualquer informação sobre sua vida. Ele alegou duas razões. Primeiro, criticou alguns pesquisadores que, aproveitando-se do grupo, haviam se comprometido em socializar o trabalho final com os seus integrantes, e não o fizeram. Ficaram decepcionados com a academia. Perceberam que foram explorados e não receberam nada em "tro- des e injustiças sociais quanto no combate ao racismo brasileiro. Ele ganha status de "movimento", porque seus integrantes têm uma clara consciência - "atitude" - de que são sujeitos de direitos civis, sociais e políticos no processo de construção da cidadania ativa. Assim, assumindo uma postura antropológica, para não cair na fragmentação da "cultura" "cultura dos idosos", "cultura dos jovens", "cultura das mulheres" etc. -, optei por utilizar a noção de "movimento", entendido como espaço de articulação e participação na luta contra as desigualdades sociais e raciais.

5 Hip Hop são dois termos ingleses cuja origem presume-se ter se construído em meados de 1968, por um dos grandes organizadores do movimento hip hop, Afrika Bambaatta. Ele teria se inspirado em dois movimentos cíclicos da sua época que se originaram nos guetos americanos, enquanto expressão de um estilo de dança popular. Daí o significado dos termos "saltar" (Hop) balançando os "quadris" (Hip). Conhecido como "Cultura de Rua", o hip hop configura-se a partir dos seguintes elementos artísticos: breaking (dança), rap (música), DJ (disc jockey) e grafite (artes plásticas).

6 Rappers são aqueles que cantam ou compõem rap. Chamam-se também MC, mestre de cerimônia, porém, devido à ampla divulgação do rap e da indústria cultural, o MC passou a ser chamado de rapper, ou seja, aquele que compõe e canta a música rap. 
7 Legitimar a "mobilidade da subjetividade como modo de produção de saber e à intersubjetividade como suporte de trabalho interpretativo e de construção de sentido para os autores dos relatos" (JOSSO, 2004, p. 23). ca”. A segunda razão foi que o grupo estava resgatando a sua própria história, sem precisar da interferência de pesquisadores de fora, eles mesmos teriam "valores morais e culturais" para escrevê-la.

Concluída a coleta das entrevistas, gravadas em 19 microfitas, fezse a transcrição minuciosa dos relatos da história oral de vida dos sujeitos (CAMARGO, 1981). O conteúdo, em seu estado bruto, foi condensado em 250 laudas de papel A4 e está gravado em uma pasta no Microsoft Word. Porém, uma fita teve algumas partes do conteúdo mal gravadas, dificultando, assim, a transcrição de alguns dados dos sujeitos envolvidos.

Uma parte da documentação foi recolhida em forma visual, chamada pelos etnólogos de imagística etnográfica (LABURTHE-TOLRA \& WARNIER, 1997, p. 433). Esta técnica compreende a etnografia feita com o auxílio da fotografia, retratando os espaços sociais em que os jovens do hip hop teresinense transitaram no processo de organização e consolidação do movimento. Utilizando este recurso técnico, construímos um acervo com 311 fotos, mas na dissertação foram usadas apenas 56, para, visualmente, ajudar o leitor a compreender os territórios nos quais estes jovens circulavam e criaram laços interpessoais com outros grupos sociais.

Como instrumental conceitual, utilizamos os estudos das Ciências Sociais que nos últimos anos têm se voltado consideravelmente para uma melhor análise da emergência do rap e do movimento hip hop, como fenômeno urbano juvenil e seus impactos e implicações sociopolítico-raciais na sociedade brasileira. Assim, alguns estudiosos da temática ganham relevância neste trabalho. Primeiramente, dois teóricos americanos: Rose (1997) e Shusterman (1998) que, embora analisem o hip hop por perspectivas diferentes, deram uma grande contribuição para esta pesquisa. Depois, na década de 1990, pesquisadores brasileiros das Ciências Sociais, da História e da Educação, como Costa (1993), Sposito (1994), Abramo (1994), Pimenta (1998), Diógenes (1998), Herschmann (1997, 2000), Dayrell (2002), Zaluar (2003), Fradique (2003) iniciaram discussões sobre novas formas socioculturais e grupos musicais juvenis nos processos de socialização vivenciados, especificamente por jovens pobres 
da periferia. Estes primeiros estudos analisam as tribos urbanas (MAFFESOLI, 2002) como novas formas e referenciais de sociabilidade juvenis. Tratando-se especificamente do rap e do hip hop, existem algumas pesquisas de pós-graduados das universidades USP e PUC de São Paulo, tais como: Andrade (1999), Azevedo (2000), Tella (2000), Lindolfo Filho (2002), entre outros.

Além destes, a pesquisa traz teóricos que trabalham as categorias: narrativa e memória. Partem, entre outros, no caso de Camargo (1981), Benjamin (1987a,b), Halbwachs (1990), Bosi (1987), Pollak (1992), Bernardo (1998), da idéia segundo a qual a narração supõe um esforço da memória para narrar experiências coletivas vividas no passado. Narrar é a arte de contar, e quando isso não acontece, corre-se o risco de perder a história oral dos sujeitos envolvidos. As experiências de vida do narrador transformam-se em experiências de vida para quem as ouve.

Concluímos afirmando que o estudo de pesquisa ganha duas importâncias: primeira, as narrativas de vida dos sujeitos ofereceram "campos significativos" que nos ajudaram a elaborar um conhecimento que até então era desconhecido no meio acadêmico, devido à escassez de estudos mais abrangentes que tratassem da temática juventude no meio urbano teresinense, especificamente nos episódios recorrentes ao lazer e aos espaços de sociabilidade urbana juvenil nas décadas 1980/90. Segundo, a análise das letras do rap revelou que este estilo musical é uma forma de narrativa contemporânea, porque, "salvando" a palavra e resgatando o poder da "fala", no sentido benjaminiano, os rappers contam, falam, tanto as suas experiências cotidianas quanto as dos outros.

\section{Breve trajetória do Movimento Hip Hop em Teresina}

A desterritorialização (APPADURAI, 1999; SANTOS, 2002) do rap americano deu-se por meio das redes ${ }^{8}$ transnacionais, cruzando fronteiras, quer através de transportes e tecnologias, quer através
8 Segundo Castells (1999), "rede é um conjunto de nós interconectados. Nó é o ponto no qual uma curva se entrecorta (...) Redes são estruturas abertas capazes de expandir de forma ilimitada, integrando novos nós desde que consigam comunicar-se dentro de rede, ou seja, desde que compartilhem os mesmos códigos de comunicação (...) Uma estrutura social com base em redes é um sistema aberto altamente dinâmico suscetível de inovação sem ameaças ao seu equilíbrio" (p. 498). 
9 "Posse" é concebida como um espaço sociocultural em que os praticantes do movimento hip hop se encontram para, com "atitude consciente", discutir os problemas da "quebrada", denunciar as formas de opressão, de racismo, violência policial, conflito familiar, descaso das autoridades etc. Além disso, deliberam as atividades culturais da posse e fazem suas performances através dos quatro elementos. Portanto, ela se caracteriza por um espaço democrático de tomada de decisões e de solidariedade entre os "manos" e "minas da quebrada". de intercomunicações por telefone, Internet, fax, fanzines, cartas, ou mesmo por meio dos encontros formais e informais, reuniões, festivais e shows. Estas redes são partilhadas e, potencialmente, absorvidas por outros tantos jovens em escala universal. Com este deslocamento, o rap, sem perder as características originais, ganha especificidade da cultura na qual é absorvido. Neste sentido, há a tendência para a opacidade entre o global e o local (HANNERZ, 1997, 1999).

No Brasil, na segunda metade dos anos 80 , assiste-se a emergência dos primeiros grupos de rap nacional, cujas temáticas retratavam (e ainda retratam) a realidade social dos jovens negros e pobres da periferia das médias e grandes cidades. Com efeito, isso demonstrava um novo cenário de configuração de novos movimentos socioculturais juvenis (ABRAMO, 1994).

Mas este contexto histórico ocorre devido às influências dos videoclips de Michael Jackson e dos filmes Beat Street (em vídeo "A loucura do ritmo", de 1984), Breakdance, Rock Steady Crew, Flashdance, New York City Breakers que explodiram no centro e na periferia de São Paulo. O grupo de rap que mais influenciou os jovens foi o Public Enemy, de Nova lorque, que enfatizava a temática da discriminação e da violência racial. Nesse contexto de influência e internacionalização da black music, surgem, inicialmente, o primeiro grupo de dança: Funk \& Cia, liderado pelo dançarino Nelson Triunfo, na rua 24 de Maio; depois, sugiram as posses ${ }^{9}$ Back Spin, Street Marriors, Crazy Crew, Hausa e Zulu Nation; finalmente, emergiram os primeiros grupos de rap nacional: Thaíde e DJ Hum, Racionais MC's, MC Jack, Código 13, Credo, e DMN (4P). Estes grupos traziam em suas letras musicais um perfil contestador e denunciante da realidade social na qual vivia e ainda vive a população negra da periferia de São Paulo. Os primeiros LPs com rap nacionais foram Hip Hop Cultura de Rua (1988) e O Som das Ruas (1989).

Em Teresina, em meados dos anos 1980, os primeiros dançarinos de breaking tiveram como referenciais os filmes Style Wars (1983), Wild Style (1983), Beat Street (1984), Breakin (1984), Rappin (1985), 
Krush Groove (1985), Break Dance; o clipe Thriller, de Michael Jackson e a novela da TV Rede Globo, Partido Alto (1984) cuja abertura era feita com alguns dançarinos do grupo de dança Funk \& Cia. Os espaços sociais foram os clubes, as escolas particulares e públicas, as ruas e praças, onde os pioneiros $B$. Boys, embalados pelo beat do rap, iniciaram suas primeiras performances para o público jovem teresinense.

No início da década de 1990, com o boom da música rap, surgiram os primeiros grupos da cidade. Os referenciais americanos foram os clipes de Rund MDC, do MC Hammer, trilha sonora do filme Collors (1992), fitas com rappers Cus Blue, e MDC Jack, Public Enemy, entre outros. Do rap nacional, beberam das batidas de Thaíde e DJ Hum, Racionais MC's e DMN (4P). Foram influenciados também pelos programas televisivos que exibiam campeonatos com jovens breakers e rappers, como o programa do Serginho Café, na TV Bandeirantes. Contudo, um referencial regional relevante foi o rapper maranhense Lamartine, que, em 1992, foi o primeiro a cantar rap para a juventude Hiphopper teresinense. Os vinis que eram solicitados em São Paulo e/ou Brasília, com o tempo não o foram mais, devido aos altos custos de transporte e correio.

Portanto, no processo de configuração do movimento, percebemos cinco fases. Primeira fase: 1980-1991 - gênese da "primeira" e "segunda escola" de breaking; segunda fase: 1992 - surgimento da primeira "escola de rappers"; terceira fase: 1992 - ocupação da Praça Pedro II pelos jovens do hip hop; quarta fase: 1993-1995 organização e autodenominação do movimento hip hop de Teresina; quinta fase: 1995-1998 - tensões internas e divisão do movimento. Assim, o hip hop, originando-se nos interstícios da sociedade, foi ganhando visibilidade social à medida que os jovens foram ocupando espaços antes freqüentados particularmente pela classe dominante. Ademais, apesar da escassez de instrumentos técnico-eletrônicos, o movimento foi se ampliando e ganhando as ruas e praças tanto no "centro" quanto na "periferia" da cidade. No tópico seguinte, analisaremos o movimento hip hop como espaço de socialização juvenil. 
10 "Circuito Jovem" foi um movimento sociocultural itinerante que surgiu no final de 1990 e se estendeu até 1997 , cujo objetivo era promover festa para os jovens nos principais bairros de Teresina. Seus bailes aglutinavam mais de três mil jovens. $O$ projeto foi criado por três radialistas: Nilo Gomes, Jorge Canalito e Lima.
Os "campos de significados", observados e interpretados a partir dos relatos de vida dos entrevistados, serviram como pontos referenciais a partir dos quais pudemos não só compreender as experiências que os sujeitos vivenciaram no passado, como também reconstruir esse passado com as idéias e imagens que têm do presente. Suas memórias individuais estão apoiadas e enraizadas nas memórias coletivas, cuja reconstrução deu-se a partir de acontecimentos que revelam, hoje, a trajetória de suas vidas no interior tanto da sociedade quanto do movimento hip hop. Pois "as memórias individuais são construídas a partir de vivências que os sujeitos experimentaram no curso de suas vidas, no interior de grupos sociais" (SANTOS, 2000, p. 5).

\section{Para Halbwachs (1990, p. 71)}

A lembrança é em larga medida uma reconstrução do passado com a ajuda de dados emprestados do presente, e, além disso, preparada por outras reconstruções feitas em épocas anteriores e de onde a imagem de outrora se manifestou já bem alterada.

Assim, através do conjunto das narrativas, pudemos mapear os territórios por que os pioneiros jovens do hip hop circularam e construíram estratégias para ocupar os espaços, tais como: os bailes do Circuito Jovem ${ }^{10}$; as apresentações nas escolas; as rodas de hip hop nas praças públicas, nas quadras, ruas e bairros da periferia; os bailes hiphoppers; as reuniões de dimensões políticas e decisórias nos bairros Mocambinho, Dirceu, na sede do PT, na Praça do Liceu e Praça Pedro II, entre outros. Estes espaços passam a ser compreendidos como locus significativos das experiências de sociabilidade juvenil, construção da cidadania e dos laços de pertencimento ao hip hop.

Este cenário mostra o quanto os jovens - além dos espaços da escola formal e da família - buscam no movimento um referencial 
social que lhes ofereça oportunidades para desenvolverem suas atividades, para buscar formas de intervenção em suas realidades, propor e cobrar respostas para suas necessidades. Neste sentido, segundo Abramo (1994, p. 223):

Os jovens tendem ir para as ruas, para os espaços públicos, para se socializarem, para buscar novas referências, para se expressar, para formatar suas identidades em confronto e interlocução com os outros. $E$ isso envolve também a eleição de pontos de referências para o desenvolvimento desses processos. Em todas as cidades, vemos lugares "conquistados" pelos jovens: em esquinas, galerias, determinadas áreas em torno de locais públicos, como praças, estações de metrô, que se tornam ponto de encontro, reunião, realização de atividades etc., normalmente freqüentados por determinadas tribos ou turmas específicas, ou que servem justamente para o encontro/enfrentamento de grupos diferentes.

Conforme Sposito (1994, p. 162), o movimento hip hop,

Ao aglutinar pequenos grupos a partir de 14 anos de idade, contempla questões importantes para a análise da sociabilidade juvenil no espaço urbano e suas formas de agir, apontando outras imagens possíveis da identidade coletiva e do conflito social na cidade.

Portanto, enquanto "cultura de rua", o hip hop em Teresina tornouse um espaço não só de entretenimento e lazer para os jovens, como também um lugar de encontro/enfretamento das diferentes tribos dos vários bairros da cidade, especificamente dos jovens negros e pobres da periferia. O hip hop foi um dos referenciais sociais a partir do qual os jovens puderam se expressar e formatar suas identidades em confronto e interlocução com os outros. Eles construíram seus próprios espaços e articularam estratégias para praticar as oficinas, encontros e performances.

Consoante a autora,

Ruas e praças da cidade são ocupadas pela presença de incontáveis agrupamentos coletivos juvenis estruturados a partir de 
galeras, bandos, gangues, grupos de orientação étnica: racista, musical, religiosa ou as agressivas torcidas de futebol. (...) Percebe-se uma nova apropriação do espaço urbano, que desafia o entendimento e exige uma aproximação mais sistemática para sua compreensão (SPOSITO, 1994, p. 162).

Portanto, graças às lembranças do passado que trazem os jovens $B$. Boys e rappers teresinenses, foi possível reconstruir esses espaços quer geográficos quer sociais por onde transitaram estes sujeitos. Suas falas revelaram as formas por que agiram não só diante dos desafios e da consolidação do movimento como também do conflito social na cidade. Evidentemente, "lembrar não é reviver, mas refazer, reconstruir, repensar, com imagens e idéias de hoje, as experiências passadas" (BOSI, 1987, p. 17). Para Matos (1998, citado por Batista \& Carvalho, 2001, p. 57), "é no grupo que os jovens identificam-se uns com os outros através de suas identidades e diferenças".

\section{Narrando as próprias temporalidades e subjetividades}

11 Neste estudo, o termo griot se refere aos antigos contadores de histórias africanos que tinham como objetivo narrar os acontecimentos passados e presentes da comunidade.

12 Marconi Apolinário dos Santos, "Preto Mais", nasceu em 22 de junho de 1988; filho de Emélia Apolinária dos Santos; casado e tem dois filhos; nível escolar: $2^{\circ}$ ano médio; atualmente trabalha em um posto de lavagem de veículos; é um educador. Entrevista concedida em sua residência, em 24 de janeiro de 2006.
A música rap (rhythm and poetry) é uma modalidade narrativa contemporânea e, sendo um dos elementos de maior poder e valorização dentro do movimento hip hop, resgata a palavra. E isso acontece por meio dos relatos que têm como base as experiências cotidianas dos sujeitos da periferia. Não são "velhos", mas adolescentes e jovens. São negros e de classe pobre, porém, verdadeiros narradores, os novos "griot" 11 contemporâneos. Eles constroem suas mensagens a partir das representações que têm do seu locus e as comunicam por meio do ritmo e da poesia, veículo acessível a uma juventude socialmente excluída. Identificando-se com este gênero musical, estes jovens falam tudo que experimentam no cotidiano: desemprego, fome, pobreza, analfabetismo, doença, morte, violência. O rap, portanto, torna-se a "poética da exclusão" (FERNANDES, 2000). Assim narrou o rapper "Preto Mais"12: 
Eu canto a minha experiência, através do que eu vejo hoje, aqui na Vila da Paz e nos bairros vizinhos, que é termo da violência, tá entendendo? É da opressão, da casa caindo, é família que não tem o que comer (...) Aqui no fundo da nossa casa passa uma grota, que quando chove é muito forte a água.

Os jovens da periferia se apropriaram da música "falada" para narrar os acontecimentos vividos na favela, no morro, na rua, na escola, na cidade, nos confrontos com a polícia, enfim, contar tudo o que ocorre tanto com suas próprias vidas quanto com as dos outros. Desta forma, podemos compreender o rap como meio de comunicação dos jovens através do qual falam tudo o que vêem, sabem, sentem e escutam sobre o seu lugar.

Os jovens do grupo de rap Flagrante ${ }^{13}$, através da música "Setor", descrevem a situação da periferia onde se encontram inseridos, quando cantam:

Eu fico analisando o que eu mais preciso, grana pra poder respirar, esquecer de tudo ou pelo menos tentar; mas não dar essa parada ainda fode a minha cabeça, só quem é do setor sabe do que eu tou falando: exploração, miséria, sangue (...), desgraça na família, ódio, e tristeza; pouca coisa para rangar em cima da mesa; alcoolismo hereditário, de pai pra filho, uma cirrose de herança para o menino; mãe desesperada de madrugada, pegando seu moleque muito louco pra dentro de casa; a feição da tia (mãe) se desmanchando em lágrimas (...); escolas galpões abandonados, educação falida, uma sala os professores e as cadeiras vazias; pois os moleques na rua, engatilhando os canos, os ferros e do que der pra matar; periferia mais do que suicida; o cemitério da quebrada vai se encher de novo esse ano (...); boteco da esquina, enchendo a cara de cachaça; 15 facadas, moleque sangrando até morrer.... ("Setor", música do CDDemo do grupo Flagrante, de Teresina-PI).

O "Setor", na compreensão dos jovens rappers, é o lugar (CASTORIADIS, 1982, p. 53) social - o bairro, a vila, a favela ou a "quebra$d a " 14$ - a partir do qual eles vivem suas temporalidades e subjetividades cotidianas. No rap, os MC's descrevem o cenário do "Setor"
13 o grupo Flagrante surgiu em 1998; já gravou um CDDemo, em 2004, em Teresina - PI, e é formado pelos rappers: WG, Gil BV, Cley, Petecão, Jean e Bira.

\footnotetext{
14 "Quebrada", na linguagem dos jovens da periferia significa o lugar onde moram, cujas representações que têm dela são: pobreza, falta de infra-estrutura, desemprego, violência policial, "tretas" entre os grupos etc. Como também lugar dos encontros, das baladas, do namoro, das festas, da solidariedade. Há uma concepção negativa construída pela mídia, quando se fala de quebrada, ou seja, lugar da malandragem, do perigo, das gangues, da violência etc.
} 
15 Gravada em 1997, a música dos Racionais MC's faz parte do selo "Sobrevivendo no Inferno". com as seguintes imagens: exploração, miséria, sangue, desgraça na família, ódio, tristeza, alcoolismo, mãe desesperada, moleque na rua, escolas abandonadas, educação falida, moleques engatilhando os canos, botecos, cachaça, 15 facadas etc. Estas são representações reais que os jovens têm da periferia. A falta de "grana para poder respirar" privam-nos de uma melhor qualidade de vida: de acesso tanto à igualdade de oportunidades quanto aos bens de consumo e serviços. Conseqüentemente, por causa disso se desencadeiam vários outros problemas.

O rapper Edy Rock, em sua música "Periferia é Periferia", conceitua a periferia a partir das seguintes imagens:

Periferia é periferia. Este lugar é um pesadelo periférico; fica no pico numérico de população. De dia a pivetada a caminho da escola; à noite, vão dormir enquanto os manos "decola" na farinha, hã! Na pedra, hã! Periferia é periferia. Milhares de casas amontoadas; em qualquer lugar, gente pobre; vários botecos abertos. Várias escolas vazias e a maioria por aqui parece comigo. Mães chorando; irmãos se matando. Até quando? Periferia é periferia. Em qualquer lugar. É gente pobre. Aqui, meu irmão, é cada um por si. Molecada sem futuro, eu já consigo ver. Aliados, drogados, então, deixe o crack de lado, escute o meu recado (...)..$^{15}$

Este rap traz como referencial a periferia, que é vista como um "espaço social inglório" (AZEVEDO, 2000). Assim, através da música, ele manifesta as representações que têm da periferia: uma realidade marcada pelo pesadelo cuja população é destituída de trabalho, saúde, educação, moradia e lazer para a "molecada".

Neste mesmo sentido, Chauí descreve as características que o termo periferia pode significar, quando diz:

A população das grandes cidades se divide entre um "centro" e uma "periferia". O termo periferia sendo usado não apenas no sentido espacial-geográfico, mas social, designando bairros afastados nos quais estão ausentes todos os serviços básicos (luz, água, esgoto, calçamento, transporte, escola, posto de 
atendimento médico), situação, aliás, encontrada no "centro", isto é, nos bolsões de pobreza, as favelas (CHAUÍ, 2000, p. 58).

O texto do rap "Setor" retrata um quadro social pelo qual Teresina vem passando nas últimas três décadas. Ele denuncia uma questão social ${ }^{16}$ que foi se complexificando à medida que a cidade foi adentrando no processo de urbanização (FAÇANHA, 1998; LIMA, 2003). Por meio das narrativas dos entrevistados, pudemos compreender que os condicionamentos conjunturais e estruturais levaram a cidade a profundas transformações em seus espaços tanto geográficos quanto sociais. Esse processo de urbanização teve como conseqüência o surgimento de duas cidades: uma que se verticalizava - a partir dos "espaços vazios" (FAÇANHA, 1998) onde surgiram os suntuosos condomínios fechados e localizados próximos aos shoppings centers, redes bancárias, hospitais, cujos aluguéis são caríssimos - ao lado das imagens de uma "outra" (LIMA, 2003) que se configurava por meio das vilas e favelas.

Neste contexto, os rappers tornaram-se os "porta-vozes" da periferia, como narrou o rapper "Preto Mais":

Eu canto a minha experiência, através do que eu vejo hoje, aqui na Vila da Paz e nos bairros vizinhos, que é termo da violência, tá entendendo? É da opressão, da casa caindo, é família que não tem o que comer (...) Aqui no fundo da nossa casa passa uma grota, que quando chove é muito forte a água. ${ }^{17}$

Enquanto a rapper Negra Li diz:

O rap é um estilo característico da periferia, a maneira como é falado, reivindicado, expressado, isso para mim é de uma importância muito grande, porque relata os fatos do nosso dia-adia, muitas coisas que vivi são faladas nas letras, não só nas minhas, mas de outras pessoas que me identifico. Sou fã dos Racionais pra caramba, gosto do Xis, do Rappin Hood. ${ }^{18}$

Os rappers são os novos narradores contemporâneos da periferia porque chamam a atenção da sociedade para as misérias sociais
16 Consoante Luiz Eduardo Wanderley, a "questão social" referese "essencialmente, às desigualdades, às injustiças e aos antagonismos que fundam a sociedade latino-americana causados pelos modos de produção, reprodução e desenvolvimento implementados nesses 500 anos no continente. Nesse sentido, a natureza da questão social se expressa em cada conjuntura sob distintas modalidades, tais como, na questão indígena, nacional, negra, rural, urbana, de gênero, atravessando aspectos econômicos, políticos, culturais, religiosos étnicos, geracionais etc." (WANDERLEY, 1996, p. 102).

17 Entrevista concedida em 24 de janeiro de 2006 .

\footnotetext{
18 Revista Rap \& Cia. Collection (2005, p. 8-11), por Alexandre de Maio, Helião e $\mathrm{Ne}$ gra Li.
} 
19 DJ Erry-G, debate: "Políticas Públicas de Juventude - Hip Hop e o Poder Público Municipal", no Fórum Hip Hop e o Poder Público Municipal, realizado em 25 de março de 2006, na Galeria Olido, São Paulo - SP em que vivem suas famílias, os operários, os negros, as crianças, os jovens. Além disso, eles também têm a função de aconselhar os "iguais-diferentes" para que não se envolvam no tráfico de drogas e na violência; que voltem para a escola, e respeitem os seus pais. O rap, portanto, tornou-se uma "máquina mortífera, uma energia que dá resistência". ${ }^{19}$

Fernandes (2000, p. 18), analisando o rap como uma "modalidade de narrativa" contemporânea, afirma:

A narrativa encaminha-se de forma a produzir um efeito catártico no leitor, ativando seu imaginário. Essa reflexão sobre o imaginário, nos tempos atuais, não pode ser realizada sem se descrever o lugar de onde se fala, e sem deixar de inscrevê-lo naquilo que se fala. O relato do rap, por se tratar de uma narrativa contemporânea explora o imaginário e a memória do ouvinte/leitor.

Conforme Boff (2005, p. 85),

A narrativa costuma ser viva e perpassada de emoção. Possui um enredo que revela o sentido das coisas narradas. Não é algo meramente conceptual, embora use conceitos. É efetivo e obedece à lógica dos sentimentos.

Assim, em uma letra de rap percebe-se o quanto o seu conteúdo está perpassado de emoção e realismo, através do qual o narrador vai revelando os fatos ou acontecimentos em que se encontram personagens a atuar e um narrador a contar as ações desses personagens. A função dos MC's é relatar as situações e ações dos sujeitos sociais. No entanto, mesmo na posição de narradores, eles não ficam fora do enredo, como um "personagem-observador"; pelo contrário, fazem parte também dos fatos, são "personagens-subjetivos" na trama das ações. Com efeito, as letras de um rap estão permeadas de subjetividades dos seus intérpretes, porque nelas encontramos elementos essenciais a uma narrativa, tais como: os personagens reais, o tempo e lugar, as causas que determinaram as situações vividas, o modo em que acontecem as situações, e as conseqüências que, eventualmente, poderão trazer às famílias, aos 
amigos, enfim, ao próprio bairro e à cidade, num contexto mais amplo. Portanto, os jovens narram fatos que revelam suas emoções, sentimentos e pensamentos, demonstrando, portanto, que também fazem parte do enredo.

Para Bosi (1987, p. 64) "a narração da própria vida é o testemunho mais eloqüente dos modos que o pessoal tem de lembrar. Ela é a sua própria memória". Na verdade, a "atividade narradora" passa por uma "prática sociopolítica" (BENJAMIN, 1987a) que tem como base as experiências coletivas ("Erfarung" = "experiência autêntica"). Walter Benjamin contrasta estas experiências autênticas àquelas modernas, entendidas como experiências vividas do choque ("Chockerlebnis"). Porque são típicas da sociedade capitalista e se caracterizam pelo indivíduo solitário. Nesta experiência fragmentada, o homem está submetido à ditadura do "tempo homogênio e vazio" (BENJAMIN, 1987b, Tese 14). Tempo dos relógios em que o homem é exilado ao mundo da produção, subordinado aos ritmos das máquinas. $E$ isso, conseqüentemente, levou ao fracasso da " $E r$ fahrung" e ao "fim da arte de contar" (GAGNEBIN, 1987, p. 9).

Nesta perspectiva, distanciando-nos de uma análise "romântica" e "nostálgica", podemos analisar o rap como narrativa construída a partir das experiências coletivas que seus intérpretes vivenciam. Através de imagens reais, os jovens falam tudo o que se passa em sua volta. Parafraseando Benjamin, eles gostam de começar sua história com uma descrição dos fatos que vão improvisar, atribuindo-os à sua própria experiência de vida (BENJAMIN, 1987a, p. 205).

Por isso, o rap, enquanto arte de persuasão, resgata o poder da palavra de convencimento e legitimidade. Não fazem suas performances somente para divertir o público juvenil, mas também para chamar-lhes a atenção para a importância de um conjunto de temáticas que devem ser levadas a sério no processo de socialização do jovem na quebrada: droga, sexo, prostituição, violência policial, desemprego, educação. Todo este conteúdo é passado pela rima dos MC's. Há uma linguagem espontânea e informal que expressa o universo semântico do jovem, socialmente excluído. Mas eles não ficam somente na denúncia, procuram também executar ações 
direta entre o narrador e sua matéria - a vida humana. Ou seja, eles trabalham a matéria-prima da experiência - a sua e a dos outros -, transformando-a num produto verdadeiro sólido, útil e único. O narrador "retira da experiência o que ele conta: sua própria experiência ou a relatada pelos outros" (BENJAMIN, 1987a, p. 201). Portanto, a arte é entendida, aqui, como experiência de vida (DEWEY, 1974).

\section{Hip Hop e Rap como referenciais para a construção de identidades étnicas}

O rapper "Preto Mais" canta em um dos trechos do Rap "Teresina Periférica":

(...) Nós da raça negra temos nosso valor, mas tem muita gente que acha que a gente é o teor, bandido, marginal, ovelha negra da classe social e coisa e tal. O mais revoltante é que todo mundo diz que preto mata e rouba, seqüestra e estupra. Eu pessoalmente, fico invocado: será que só os brancos são honestos de verdade? (...). ${ }^{21}$

A linguagem do narrador é a da oralidade cotidiana e assaz informal. Ele mostra a realidade do negro no meio urbano teresinense. Durante nossa entrevista, à noite, em frente à sua casa, ao pé de um poste de luz, ele narrou:

Eu canto a minha experiência, através do que eu vejo hoje, aqui na Vila da Paz e nos bairros vizinhos, que é termo da violência, tá entendendo? É da opressão, da casa caindo, é família que não tem o que comer (...). Aqui no fundo da nossa casa passa uma grota, que quando chove é muito forte a água.

Neste contexto de destituição social, o narrador identifica os personagens que residem na periferia: "nós da raça negra". Subjetivamente, assume sua negritude e exalta o valor da raça negra, quando completa a frase: "temos o nosso valor". Há uma auto-estima, uma valorização da comunidade ${ }^{22}$ negra. Geograficamente, mora na pectivas funções (www. rapnacional.com.br). O Movimento Hip Hop Pela Paz na Periferia - MP3 - oferece vários cursos profissionalizantes, tais como: informática, artes plásticas, manutenção de computadores, oficinas culturais, confecção de roupas. Atualmente são mais de 750 jovens da periferia. Dentre estes, para o serviço de artes plásticas, 25 já estão empregados. Segundo o coordenador do projeto, Francisco Júnior, o MP3 procura não só capacitar e inserir o jovem no mercado de trabalho formal, como também resgatar a sua auto-estima (Entrevista concedida no dia 22.01.2006). O Centro de Referência Hip Hop do Piauí - CRHHP -, coordenado pelo Movimento Hip Hop "Questão Ideológica", vem desenvolvendo alguns projetos de políticas de geração de trabalho e renda, em parceria com o SEBRAE e a Fundação Banco do Brasil. O centro, semanalmente, promove oficinas - dança, rap, $D J$ e grafite - para mais de mil adolescentes dos bairros carentes de Teresina. Além disso, através do projeto "Fome de Cultura na Quebrada", incentiva crianças, adolescentes e jovens tanto para a leitura quanto para a pesquisa. Este conjunto de políticas preventivas faz com que os jovens ocupem seu tempo com um maior número de atividades não só profissionalizantes como também socializantes (Entrevista com seu coordenador, Cley Flanklin Romão, no dia 21.01.2005). A ONG Zulu Nation Brasil, coordenada 
pelo Mano King Nino Brown, um dos pioneiros fundadores do movimento hip hop Paulista - na década de 80 -, tem como objetivo disseminar os elementos do hip hop, utilizando-os para promover a consciência étnica e cidadã dos jovens negros e pobres da periferia da cidade. As ações do projeto visam solucionar os problemas que mais atingem os jovens: a violência, o uso de drogas, a discriminação racial e social, a gravidez na adolescência, as DST/AIDS, a desigualdade de gênero. A ONG teve origem nos EUA, na década de 70 , por um dos maiores articuladores do movimento, Africa Bambaataa. A Zulu National está espalhada por alguns países da África e da Europa (Fonte: Folder da ONG Zulu Nation Brasil, 2005).

21 o rap "Teresina Periférica", do grupo União de Rapper, é uma música inédita e ainda não foi gravada em CD.

22 O sentido de "Comunidade", neste trabalho, ganha o sentido teorizado por Edgar Morin ao mostrar a distinção entre Sociedade e Comunidade. Diz ele: "definimos comunidade (Gemeinschaft) como um conjunto de indivíduos ligados afetivamente por um sentimento de pertencimento a um Nós..." (MORIN, 1997, p. 147)

23 Entrevista concedida em 24 de janeiro de 2006 .

24 Neste trabalho, a categoria "afro-brasileiro" compreende todos(as) aqueles(as) que, a partir de uma estraté- favela, próximo a uma grota, é pobre e humilde, mas não é marginal. O narrador mostra que os qualificativos - favelado, pobre, humilde - não são motivos para diminuir o valor do negro como cidadão, mas estes qualificativos, por si mesmos, denunciam as desigualdades sociais entre os negros e brancos brasileiros.

A frase - "nós da raça negra temos o nosso valor" - é reflexo de uma consciência cidadã ativa e politizada de quem assume a identidade étnica. Inclusive ouvimos desse narrador o seguinte relato: "Nós temos valor, temos força, nossa raça é muito poderosa pra se omitir à toa. Então, vamos lutar, quem é negro e que tem amor à sua raça". ${ }^{23}$

Esta atitude de auto-estima é resultado de um processo de luta do movimento negro que ao longo dos últimos vinte anos vem trabalhando a questão racial nas escolas, nas igrejas, nas comunidades eclesiais de base, nas instituições políticas e no movimento hip hop. Percebe-se que a dimensão étnica vem sendo utilizada como referencial para a composição das letras do rap nacional. Não só para mostrar a auto-estima dos afro-brasileiros ${ }^{24}$, mas, sobretudo, para identificar o poder que a música tem para denunciar e transformar as estruturas de exclusão e discriminação brasileiras.

Certa vez, um dos MC's expressou a seguinte frase: "a senzala está nova, pode crer, está bacana, virou favela urbana, no pé do morro". Este grau de consciência de classe demonstra o conhecimento que os jovens negros e pobres têm da história do escravo no Brasil. Conhecedores das péssimas condições das senzalas do período da escravidão, hoje comparam-nas com as formas de habitação dos morros, das encostas, das margens de córregos, onde se instalam as favelas. Portanto, atualmente, as novas senzalas estão nos morros da periferia. Segundo Silvério (2002, p. 52),

No Brasil, no entanto, existiu e existe uma tentativa de negar a importância da raça como fator gerador de desigualdades sociais por uma parcela significativa dos setores dominantes. Só muito recentemente vozes dissonantes têm chamado a atenção sobre a singularidade de nossas relações raciais. 
Assim, o rap traz à tona a questão racial, convidando toda a sociedade brasileira à discussão de uma temática que - dada a sua complexidade, suas implicações e seus deslizes nas suas várias formas de interpretação - precisa ser enfrentada por todos os cidadãos, pelas instituições sociais e religiosas e pelo sistema educacional. Além disso, os narradores mostram que o rap e o hip hop, além de serem espaços de sociabilidade juvenil, são também espaços de construção das identidades étnicas. Por meio das entrevistas, percebemos que muitos jovens negros passaram não apenas a gostar de si mesmos, como também a defender os atributos da comunidade afro-brasileira.

Algumas narrativas nos ajudam a compreender o hip hop como um espaço de construção de identidade étnica. Assim, para o B. Boy "Re", o movimento contribuiu muito para que ele gostasse de sua cor. Narrou:

Eu acho me assumindo realmente como negro; de gostar de ser negro e valorizar essa cultura tão bonita, né, que é a cultura negra. E eu acho que o hip hop foi fundamental nesta questão. Acho que não só aqui em Teresina, como no Brasil todo. A questão da informação da cultura negra, que a gente não sabia, foi muito fundamental para a auto-estima de muitas pessoas; inclusive pra minha mesmo, foi fundamental essa questão do hip hop. O rap e hip hop me ajudaram bastante tanto na auto-estima, como na cultura, no conhecimento de gostar de tudo: de gostar de ser negro, ser negro mesmo, se assumir mesmo, acho que foi uma questão principal o hip hop aqui, em Teresina. ${ }^{25}$

Importante frisar que o narrador, passando a "gostar de ser negro", descobriu o quanto a cultura afro-brasileira não só era "bonita" como também fundamental tanto para a auto-estima do negro quanto para estimulá-lo a resistir aos racismos e às discriminações. Através do qualitativo: "bonita", o narrador identifica o quanto essa cultura é rica em bens culturais. O hip hop foi fundamental para a construção de sua identidade. Esta não pode ser analisada como ente fixo, fechado em um conceito essencialista (HALL, 2003), senão como um cons- gia política, e levando em consideração os critérios do IBGE ("preto" ou "pardo"), se autodenominam "negros" ou "pretos" brasileiros e que desenvolvem bens culturais materiais ou espirituais com bases nas raízes das culturas africanas da diáspora, e as utilizam como estratégias sóciopolítico-culturais para auto-afirmação de sua identidade racial e de reconhecimento de sua pertença ao povo brasileiro (LINDOLFO FILHO, 2002).

25 Entrevista concedida em 21 de janeiro de 2005 . 
truto social e cultural, porque os símbolos e significados são partilhados pelos sujeitos em discussão, entre eles, mas não dentro deles. Pois:

Ela é um processo de construção que não é compreensível fora da dinâmica que rege a vida de um grupo social em sua relação com os outros mundos distintos, resultando, assim, de um processo e de uma construção em um contexto (MONTES, 1996, p. 56 citado por OLIVEIRA, 1999, p. 94).

Para Montes, "identidade étnica" é:

A identidade de um grupo que se diferencia dos outros por um conjunto de características étnicas e que tem formas de cultura, costumes, valores, etc. que lhes são próprios (p. 96).

Então, a construção da identidade étnica dá-se dentro da "tensão dialética entre o eu e o outro, no contexto social, e pressupõe o reconhecimento das semelhanças e diferenças para a sua afirmação" (p. 94). Infelizmente, no contexto social brasileiro, o diferente tornou-se sinônimo de "perigo" para a classe dominante.

Por meio da narrativa do $B$. Boy "Re", percebemos o aspecto socioeducativo do hip hop. Graças a ele, o B. Boy passou a conhecer melhor a cultura africana; criou gosto e se interessou pela mesma. Similar ao breaker, muitos jovens, depois que começaram a participar do movimento, tiveram acesso às autobiografias de Malcolm X, Nelson Mandela, Zumbi dos Palmares, Martin Luther King e Esteve Biko.

Influenciados por tais personalidades negras, passaram a se projetar nos espaços sociais, compor músicas e conscientizaram-se de que, embora morando nas favelas e vilas, seriam sujeitos de uma cidadania ativa; outros jovens, entrando no movimento negro, assumiram os atributos afros, a estética negra; e muitos outros se engajaram em partidos políticos. Por outro lado, este referencial foi também uma estratégia social e política por onde os sujeitos se defenderam e ainda se defendem do preconceito social e lutaram por políticas sociais e cidadania, como disse Mauro: "não abaixar a cabeça". O rapper Washington Gabriel ${ }^{26}$ narrou que, depois de ter 
conhecido o hip hop, passou "a ver a coisa de outra forma", porque até então somente conhecia a história da África a partir dos livros "didáticos" oficiais.

O B. Boy Mauro relata como o hip hop o fez se conscientizar da sua negritude, sobretudo depois que se envolveu com a dança breaking:

Sou negro. Graças a Deus, o Hip Hop me mostrou o quanto essa etnia é poderosa, o quanto de poder, primeiro, enquanto seres humanos; e, depois, com a classificação socialmente herdada. Mas foi muito bom. Eu tirei uma carga tão pesada de minhas costas, quando eu descobri meu valor como negro; foi um renascimento (...) ter descoberto meu valor como negro, e o Hip Hop fez isso; ele me mostrou meu valor como negro: isto foi ótimo. ${ }^{27}$

Percebemos que a noção de "etnia poderosa" foi construída pelo $B$. Boy Mauro através do hip hop. Neste locus, ele compreende o valor da cultura afro-brasileira, que sobreviveu ao longo do tempo, apesar da escravidão e da dominação da cultura européia. Reconhece o legado herdado da cultura africana na diáspora. Porém, teve que fazer uma terapia mental, porque tirou de si um "peso" quando descobriu seu valor enquanto negro; foi um "renascimento". Aqui, poder-se-ia dizer que houve um rito de passagem porque, ao assumir ser negro, transmutou-se de um estado anterior de ignorância para um nível de consciência e descoberta da "nova" vida.

Assim, em meados dos anos 1990, a questão racial passava a se inserir nas letras e discursos dos rappers. Uma postura agressiva e de enfrentamento à sociedade dominante encontrava-se nas diversas letras dos pioneiros MC's. Exemplificando: os Racionais MC's - com as letras "Racistas otários" e "Negro limitado" - e Rappin' Hood cantando "Sou negrão" e "Tributo às mulheres pretas", com um discurso mais afirmativo - refletiam um contexto de muita afirmação e resgate do orgulho de "ser" negro. Ademais, percebe-se uma maior aceitação e apropriação do termo "preto", transformando-o de designação depreciativa em motivo de orgulho.

Contudo, hoje, parece-me que a discussão étnico-racial, no interior do movimento, diferentemente da década de 90 , vem perdendo
26 Washington Gabriel Cruz, conhecido como WG, nasceu em Teresina, em $1^{\circ}$ de janeiro de 1975. Filho de Benevinuto Lopes da Cruz Neto e Maria Gabriel de Sousa Cruz. Não chegou a terminar o $2^{\circ}$ Grau. Por um longo tempo trabalhou como farmacêutico. Casou com Jaqueline Ferreira Cruz, com quem teve dois filhos. Atualmente é um dos coordenadores da Associação Movimento Hip Hop Organizado do Piauí.

27 Entrevista concedida em 25 de janeiro de 2005. 
a sua força política. Aquela corrida dos pioneiros, em busca de leituras sobre os líderes negros, símbolo da luta pelos direitos individuais, civis e políticos, já não existe mais e os líderes tornaram-se pouco relevantes para os integrantes do hip hop atual.

\section{Considerações finais}

O estudo de pesquisa concluiu que o rap retoma a "redenção" da palavra no instante em que os sujeitos resgatam o direito de falar, de contar suas próprias histórias de oprimidos. Nele encontra-se uma matriz afro-brasileira, sobre a qual há a produção de uma "nova" música. "Nova" porque os DJs e rappers criam um lugar de originalidade, que acaba se diferenciando das músicas nas quais buscaram referências, e que fazem do Rap algo que não se assemelha aos outros estilos, como o samba, o reggae ou o soul. Assim, o rap é um ritmo que está permanentemente sendo retrabalhado, ressignificado, tornado contemporâneo de forma criativa e inovadora. $E$ isso ocorre tanto em Teresina quanto em vários centros urbanos brasileiros.

Três aspectos poder-se-iam abrir a novas discussões em torno do rap. Primeira, do ponto de vista de alguns críticos, o rap exibe apenas uma forma fantasmagórica da lógica cultural do capitalismo tardio (ROSE, 1997). Para estes críticos, levando em conta a comercialização, o movimento alcançou contornos transnacionais porque foi "incorporado" ao mundo da indústria da cultura. Passando de fenômeno de emergência localizada e das múltiplas influências culturais, tornou-se um fenômeno acessível, consumível, identificável e mediatizado. Ou seja, saindo daqueles espaços à margem do processo de comercialização, circunscrito aos espaços públicos alternativos, ele alcançou status de música industrializada cujo fim foi a produção de bens culturais que atendessem o maior público possível. A partir de então, o rap invadiu os meios de comunicação de massa, atingiu um público mais vasto do que o original do gueto, conquistando, portanto, uma platéia real para sua música e sua mensagem, mesmo na América branca e na Europa. 
Por outro lado, há críticos otimistas que dizem que não se deve confundir o rap apenas como uma música do mercado de consumo. Para estes, faz-se necessário compreender que os momentos de sua "incorporação" ao mercado devem ser interpretados como uma transformação na relação que o movimento sempre manteve com o consumo. Ou seja, esta relação de consumo deve ser entendida a partir das atitudes de DJs e rappers, como os rappers americanos, que investem muitos dólares em equipamentos tecnológicos, a fim de que possam produzir "ritmos mais possantes". E, se isto ocorreu nas décadas de 70/80, foi porque havia um "mercado hip hop" "centralizado nas comunidades negras e hispânicas de Nova York" (ROSE, 1997). Daí, a mudança na orientação do hip hop em relação ao mercado tem que ser analisada a partir da mudança sobre o escopo e a direção do processo de obtenção de lucro, que saiu de grandes empresários negros e hispânicos para as mãos de grandes empresários brancos de multinacionais.

No Brasil, a incorporação do hip hop e do rap ao mercado de consumo encontra-se ainda em um processo de contínua ascensão e expansão, porque, saindo da classe popular e negra, começa a atingir as classes média e alta. Pois jovens brancos destas classes já "curtem", em suas baladas, alguns dos raps, tanto norteamericano quanto brasileiro.

Neste sentido, os grupos de rap underground, apoiados em uma "atitude consciente", vêm lutando por políticas públicas alternativas cujo fim é a geração de renda para a juventude pobre da periferia. Há, então, trabalhos de parceria entre os vários grupos na composição de letras, na divulgação de shows, nas confecções de camisetas, na venda de CDs e clipes dos grupos, nos programas de emissoras comunitárias, nos trabalhos coletivos através de oficinas de breaking, rap, discotecagem e grafite. As "posses", portanto, fazem um trabalho sócio-educativo que tem como estratégia política discutir questões sociais como: gênero, raça, violência, educação, geração de renda, emprego, entre outras.

Finalmente, percebe-se uma forte "masculinização" do rap. Isso foi possível devido ao seu processo de comercialização e midiatização. Contudo, as mulheres tiveram um papel relevante na criação e 
consolidação do hip hop, o qual, por sua vez, tem Ihes possibilitado, também, uma visibilidade discursiva, onde exprimem os seus problemas, preocupações e críticas (FRADIQUE, 2003, p. 46).

Observamos que, em Teresina, a inexistência da presença feminina no hip hop denuncia o lado machista do movimento nesta cidade. A questão de gênero é algo ainda bastante complexa, intrigante e instigante para os integrantes do movimento. Entretanto, as rappers "Preta Cristiane", Amanda e Naira foram pioneiras e buscaram quebrar o poder da masculinização no interior do hip hop. Assim, o grupo "Atitude Feminina”, surgiu em 2000, denunciando o lado machista, discriminativo e preconceituoso da sociedade em relação à mulher negra. Desde então, o grupo passou a conscientizar as adolescentes negras e pobres das favelas e vilas a não se venderem como objeto de satisfação sexual. O grupo têm também sido referencial para outras adolescentes que não só simpatizam como também entram no movimento e, com o tempo, decidem praticar qualquer um dos elementos do hip hop.

Resumo: O objetivo principal deste artigo consiste em discutir a importância da música rap e do hip hop para a socialização dos jovens da periferia de Teresina-PI. A pesquisa, baseada em relevantes aportes teóricos sobre "memória" e "narrativa", analisa o rap como uma "nova forma de narrativa" contemporânea. Optamos também pela história oral de vida como técnica qualitativa porque as narrativas dos sujeitos entrevistados nos ajudaram a mapear os espaços de sociabilidade juvenil, reconstruir a trajetória do movimento hip hop e analisar as implicações do hip hop e do rap na construção das identidades étnicas desses jovens.

Palavras-chave: Hip Hop, Rap, narrativa, memória, sociabilidade juvenil, identidade étnica. 


\begin{abstract}
The main objective of this article consists in arguing about the importance of Rap and Hip Hop music for the youth socialization in Teresina's outskirts. The research based on significant theoretical studies about "memory" and "narrative" shows that Rap is a new form of contemporary narrative. We also opted for verbal life history as a qualitative technique because the interviews helped us map youthful socialization spaces, reconstruct the Hip Hop Movement trajectory and analyze Hip Hop and the Rap implications in the construction of these youth's ethnic identity.
\end{abstract}

Key words: Hip Hop, Rap, narrative, memory, youthful socialization, ethnic identities.

Resumen: El objetivo principal de este artículo consiste en discutir la importancia de la música rap y del hip hop para la socialización de los jóvenes da periferia de Teresina-PI. La investigación, com base en relevantes aportes teóricos sobre "memoria" y "narrativa", analisa el rap como una "nueva forma de narrativa" contemporanea. Asimismo, optamos por la historia oral de vida como técnica cualitativa porque las narrativas de los sujetos entrevistados nos ayudaron a mapear los espacios de sociabilidad juvenil, reconstruir la trajetória del movimiento hip hop y analisar las implicaciones del hip hop y del rap en la construcción de las identidades étnicas de esos jóvenes.

Palabras clave: Hip Hop, Rap, narrativa, memoria, sociabilidad juvenil, identidad étnica. 


\section{Bibliografia}

ABRAMO, H. W. Cenas juvenis - punks e darks no espetáculo urbano. São Paulo: Scritta, 1994.

ANDRADE, E. N. (org.). Rap e educação. Rap é educação. São Paulo: Summus, 1999.

APPADURAI, A. Disjunção e diferença na economia cultural global. In: Cultura global: Nacionalismo, globalização e modernidade. $3^{\mathrm{a}}$ ed. Petrópolis: Vozes, 1999.

AZEVEDO, A. M. Grillu. No ritmo do Rap: Música, cotidiano e sociabilidade negra. São Paulo, 1980-1997. (Dissertação de mestrado em história) São Paulo, PUC, 2000.

BATISTA, J. D. de A. \& CARVALHO, S. S. As múltiplas formas de expressão da sociabilidade juvenil. In: DAMASCENO, M. N.; MATOS, K. S. L de.; VASCONCELOS, J. G. (Orgs.). Trajetórias da juventude. Fortaleza: Edições UFC. Cadernos de Pós-Graduação em Educação, 2001. p. 57-83.

BENJAMIN, W. O Narrador - considerações sobre a obra de Nikolai Leskov. In: Magia e técnica, arte e política: Ensaios sobre literatura e história da cultura. Obras escolhidas, $3^{a}$ ed., São Paulo: Brasiliense, v. 1, p. 197-221, 1987a.

"Sobre o conceito da história". In: Magia e técnica, arte e política. Ensaios sobre literatura e história da cultura. $3^{\mathrm{a}}$ ed. Obras escoIhidas. São Paulo: Brasiliense, v. 1, p. 222-232, 1987b.

BERNARDO, T. Memória em branco e preto: olhares sobre São Paulo. São Paulo: EDUC, Fundação Editora da UNESP, 1998.

BOFF, L. Virtudes para um outro mundo possível. In: Hospitalidade: direito e dever de todos. Petrópolis: Vozes, v. 1., 2005.

BOSI, E. Memória e sociedade: Lembranças de velhos. $2^{\mathrm{a}}$. ed. São Paulo: T. A. Queiroz/EDUSP, 1987.

CAMARGO, A. História oral: catálogo de depoimentos. Rio de Janeiro: FGV, CPDOC, 1981.

CASTELLS, M. A sociedade em rede. São Paulo: Paz e Terra, 1999.

CASTORIADIS, C. A Instituição imaginária da sociedade. $3 .^{a}$ ed. Rio de Janeiro: Paz e Terra, 1982. 
CHAUI, M. Brasil: mito fundador e sociedade autoritária. São Paulo: Perseu Abramo, 2000.

CHAVES, J. M. Como nasceu Teresina. In: Cadernos Históricos. Teresina: Fundação Cultural Monsenhor Chaves, 1993. p. 25-54.

COSTA, M. R. Os "carecas do subúrbio": Caminho de um nomadismo moderno. Petrópolis, Vozes, 1993.

DAYRELL, J. O rap e o funk na socialização da juventude. In: Educação e Pesquisa. São Paulo, v. 28, n. 1, p. 117-136, jan./jun. 2002.

DEWEY, J. A arte como experiência. In: Os Pensadores. Tradução de Murit O. R. P. L. São Paulo: Abril Cultural, cap. 3, v. 15, p. 247-263, 1974.

DIAS, M. O. L. da S. Política e sociedade na obra de Sérgio Buarque de Holanda. In: CÂNDIDO, A. (Org.). Sérgio Buarque de Holanda e o Brasil. São Paulo: Fundação Perseu Abramo, 1998.

DIÓGENES, G. Cartografias da cultura e da violência: Gangues, galeras e o movimento Hip Hop. São Paulo: Annablume; Fortaleza: Secretaria da Cultura e Desporto, 1998.

FAÇANHA, A. C. A evolução urbana de Teresina: Agentes, processos e formas espaciais da cidade. (Dissertação de Mestrado) - Recife: Universidade Federal de Pernambuco, 1998.

FERNANDES, M. das G. Conto e música: diálogo com as periferias. In: Literatura e Crítica: estudos contemporâneos. Núcleo de Assessoramento à pesquisa. Faculdade de Letras/UFMG. Cadernos de Pesquisa, Belo Horizonte: n. 39, out. 2000.

FRADIQUE, T. Fixar o Movimento: Representações da Música Rap em Portugal. Lisboa: Publicações Dom Quixote, 2003.

GAGNEBIN, J. M. Prefácio: Walter Benjamin ou a história aberta. In: BENJAMIN, W. Magia e técnica, arte e política: Ensaios sobre literatura e história da cultura. Obras escolhidas, $3^{\text {a }}$ ed. São Paulo: Brasiliense, v. 1, p. 7-19, 1987.

História e narração em Walter Benjamin. São Paulo: Perspectiva, Campinas: FAPESP, p. 142, 1994. (Coleção Estudos)

GASKELL, G. Entrevistas individuais e grupais. In: BAUER, M. W. e GASKELL, G. Pesquisa qualitativa com texto, imagem e som. Petrópolis: Vozes, 2002.

GEERTZ, C. A interpretação das culturas. Rio de Janeiro: LTC, 1989. HALBWACHS, M. Memória coletiva. Petrópolis: Vozes, 1990. 
HALL, S. A Identidade cultural na pós-modernidade. $8^{\mathrm{a}}$ ed. Rio de Janeiro: DP\&A, 2003.

HANNERZ, U. Fluxos, fronteiras, híbridos: palavras-chave da antropologia transnacional. Revista Mana, Rio de Janeiro, v. 3, n. 1 , abr. de 1997.

Cosmopolitas e locais na cultura global. In: Cultura global: nacionalismo, globalização e modernidade. $3^{\mathrm{a}}$ ed. Petrópolis: Vozes, 1999.

HERSCHMANN, M. (Org.). Abalando os anos 90 funk e hip-hop: globalização, violência, e estilo cultural. Rio de Janeiro: Rocco 1997. 2000.

JOSSO, M.-C. Experiências de vida e formação. São Paulo: Cortez, 2004.

LABURTHE-TOLRA, P. \& WARNIER, J.-P. Etnologia antropologia. Petrópolis: Vozes, 1997.

LIMA, A. J. de. As multifaces da pobreza: Formas de vida e representações simbólicas dos pobres urbanos. Teresina: Halley, 2003.

LINDOLFO FILHO, J. Tribos urbanas: O rap e a radiografia das metrópoles. Tese de doutorado em ciências sociais. São Paulo: PUC, 2002.

MAFFESOLI, M. O tempo das tribos: O declínio do individualismo nas sociedades de massa. $3^{a}$ ed. Rio de Janeiro: Forense Universitária, 2002.

MATOS, K. S. L. de. Identidade e representações sociais: construções do eu com o outro. (1998d). In: THERRIEN, Â. de S. T., MATOS, K. S. L. de. (Orgs.). Identidade e representações sociais. Fortaleza: Edições UFC. Cadernos de pós-graduação em Educação, 1998d.

MORIN, E. Cultura de massas no século $X X-$ Neurose, $9^{a}$. ed. Rio de Janeiro: Forense Universitária, v. 1, 1997.

NASCIMENTO, F. A. do. A cidade sob o fogo: Modernização e violência policial em Teresina (1937-1945). Teresina: Fundação Cultural Monsenhor Chaves, 2002.

OLIVEIRA, S. C. de. Para uma análise sociossemiótica do discurso presente no texto da música Rap. (Tese de doutorado) - São Paulo: USP, 1999. 
OLIVEN, R. G. A antropologia de grupos urbanos. $5^{\text {a }}$ ed., Petrópolis: Vozes, 2002.

PIMENTA, C. A. M. O Cotidiano dos grupos de jovens da periferia de São Paulo: visões de um mundo e manifestações de ética e violência. In: Demandas Sociais, Taubaté: NIPPC, v. 1. n. 2, p. 35-47, jul/dez. 1998.

POLLAK, M. Memória e identidade social. Estudos históricos, Rio de Janeiro, v. 5, n. 10, 1992.

RAP \& CIA COLLECTION. DE MAIO, A.; HELIÃO \& NEGRA LI, n. 1, p. 811, out. 2005.

REALHIPHOP. Disponível em: <http://www.realhiphop.com.br/institucional/historia.htm>.

ROSE, T. Um estilo que ninguém segura: política, estilo e a cidade pósindustrial no hip hop. In: HERSCHMANN, M. (Org.). Abalando os anos 90: Funk e Hip Hop: globalização, violência e estilo cultural. Rio de Janeiro: Rocco, 1997.

SANTOS, A. C. de A. Fontes orais: testemunhos, trajetórias de vida e história. Departamento de História Universidade Federal do Pará. Revista Via Atlântica, n. 4, p. 1-10, 2000.

SANTOS, B. de S. (org.). Globalização e as ciências sociais. 2. ${ }^{a}$ ed. São Paulo: Cortez, 2002.

SHUSTERMAN, R. Vivendo a arte: O pensamento pragmatista e a estética popular. São Paulo: Editora 34, 1998.

SILVA, A. E. N. da. A Bruxa má de Teresina: Um estudo do estigma sobre a Vila Irmã Dulce como um "lugar violento" (1998-2005). (Dissertação de mestrado em políticas públicas). Universidade Federal do Piauí, Teresina, 2005.

SILVA, L. S. da. Traficando informações - do Bronx ao Piauí: Itinerários do movimento Hip Hop. Trabalho de conclusão do curso de História. Teresina: UFPI, 2002.

SILVÉRIO, V. R. Ação afirmativa e o combate ao racismo institucional no Brasil. Caderno de Pesquisa n. 117. São Paulo, nov. 2002.

SPOSITO, M. P. A sociabilidade juvenil e a rua: novos conflitos e ação coletiva na cidade. Tempo Social: Revista Social, USP, São Paulo, 5 (1-2): 161-178, 1993 (editado em nov. 1994). 
Silva, A. L. da. Música rap: narrativa dos jovens da periferia de Teresina - PI

TELLA, M. A. P. Atitude, arte, cultura e autoconhecimento: Rap como voz da periferia. Dissertação de mestrado em Antropologia. São Paulo: PUC, 2000.

WANDERLEY, L. E. W. Rumos da ordem pública no Brasil: a construção do público. São Paulo em Perspectiva, São Paulo: SEADE, v. 10, n. 4. p. 96-106, out/dez 1996.

ZALUAR, A. Gangues, galeras e quadrilhas: globalização, juventude e violência. In: VIANNA, H. (Org.). Galeras cariocas: Territórios de conflitos e encontros culturais. Rio de Janeiro: UFRJ, 2003.

e-mail: antonioleandrodasilva@yahoo.com.br

Recebido em 30/08/2006.

Aceito em 20/09/2006. 